\title{
Adopted Pedagogies: Nahua Incorporation of European Music and Theater in Colonial Mexico City
}

$\mathrm{I}$ n 1519 Spanish conquistadors arrived on the shores of Mesoamerica under the leadership of Hernando Cortés. Following the defeat of Mexico-Tenochtitlan, the Aztec capital, Cortés requested that members of the Franciscan order be sent from Spain to lead the conversion effort. In 1523 the first three Franciscans arrived, among them fray Pedro de Gante. One year later another 12 Franciscans made the journey. They established themselves in the southeastern portion of Mexico-Tenochtitlan, and under their direction Nahua laborers built the principal Franciscan religious compound, San Francisco, and the first indigenous chapel in New Spain, San Josef de los Naturales. Together this friary and chapel served as the main point of interaction for Franciscan conversion efforts within the altepetl, ethnic state, of Mexico-Tenochtitlan. In the courtyard of San Francisco, next to the indigenous chapel, fray Pedro established an indigenous school aimed at the indoctrination of the Nahua peoples of Mexico-Tenochtitlan and other outlying altepetl. Although its students were primarily members of indigenous nobility, other promising Nahuas received an education there as well.

Nahua religion during the precontact period possessed a certain amount of theatricality, such as the costumes used in ritualized combat. ${ }^{1}$ Noting this and the Nahuas' love of music, the Franciscans incorporated music and theater into the religious curriculum of their schools. They hoped that their use as pedagogical tools would encourage wider acceptance of Christianity. The Nahuas adopted both traditions and integrated them into their culture and society. By the end of the sixteenth century, the Nahuas added singing and musical instruments to their plays, festivities, and religious ceremonies. Moreover, they fully engaged in the performance, writing, and editing of dramas in Nahuatl, some sponsored by friars and others undertaken wholly by themselves. ${ }^{2}$

1. Jaime Lara, Christian Texts for Aztecs: Art and Liturgy in Colonial Mexico (Notre Dame: University of Notre Dame Press, 2008), p. 201.

2. Barry D. Sell and Louise M. Burkhart, Nahuatl Theater Volume I: Death and Life in Colonial Nahua Mexico (Norman: University of Oklahoma Press, 2004), p. xix. 
Though encouraged by the friars, the Nahuas willingly made many elements of their Christian education their own and added them to their traditions. By the end of the seventeenth century, aspects of their Christian practices (which they had adopted during the sixteenth century under the guidance of their chaplains) were deemed to have pagan tendencies. While ecclesiastics fought to remove these heretical practices, the Nahuas strove to keep them, citing ancestral tradition. This raises the question of who was responsible for cultural expressions within Nahua Christianity: the ecclesiastics who introduced the pedagogical tools of theater and European music or the Nahua parishioners, musicians, and actors who used them in the practice of Nahua Christianity? This article examines how the Nahuas of Mexico City interacted with and incorporated European music and theater education into their community. In the process of learning about the tenets of Catholicism through theater and music the Nahuas not only adopted both European art forms, but they also altered them, at points combined them, and made them a part of their "ancestral traditions."

The use of Nahua theatrical performances built on other pedagogical tools, such as music, but also added another dimension to the learning experience, that of having students teach the rest of the Nahua community through performative example. Additionally, the process of writing and translating these performances placed literate Nahuas in a position to incorporate aspects of their culture and understanding of Catholicism into the plays, as it was the Nahuas who wrote, translated, edited, and incorporated their own music and images into the performances. By examining both the adoption and expansion of theater and music in the Nahua community of Mexico City this paper adds to current understandings of indigenous Catholicism in New Spain.

Gabriel Saldivar y Silva, with the collaboration of his wife, Elisa Osorio Bolio de Saldivar, broke new ground in colonial and early independence era history with the 1934 publication of Historia de la música en México. ${ }^{3}$ Eighteen years later Robert Stevenson published his essential monograph, Music in Mexico, followed in 1976 by Music in Aztec and Inca Territory. Stevenson's studies furthered the work of Saldívar y Silva by focusing on indigenous music in the pre-Hispanic and colonial periods. Both authors used published primary and archival sources, especially the work of Spanish chroniclers, and, in addition, Stevenson used translations of Nahuatl sources such as Rémi Siméon's Annales de Chimalpabin Quaubtlehuanitzin. ${ }^{4}$

More recently, work by Eloy Cruz and Lourdes Turrent has expanded on Saldívar y Silva's and Stevenson's achievements. Turrent's study, La conquista musical de

3. Gabriel Saldivar, Historia de la música en México (Méxcio: Secretaria de Educación Pública,1934).

4. Robert Stevenson, Music in Mexico: A Historical Survey (New York: Thomas Y. Crowell Company, 1952); and Robert Stevenson, Music in Aztec of Inca Territory (Berkeley: University of California Press, 1976). 
México (1993), examines music in its symbolic and social roles and the changes it underwent during the early colonial period. Though smaller in size, the 2001 article by Cruz, "De cómo una letra hace la diferencia," is essential in its efforts to clear up confusion surrounding the authorship of two pieces of Nahuatl polyphonic sheet music, a problem that Stevenson wrestled with. ${ }^{5}$ My article builds on the work of these scholars and others by benefiting from a growing corpus of extant Nahuatl sources, both published and archival. Central to this study has been an expanding collection of indigenous testaments from Mexico City and translations of Nahua annalist don Domingo de San Antón Muñon Chimalpahin Quauhtlehuanitzin, by Susan Schroeder, and transcriptions and translations of Nahuatl dramas, by Fernando Horcasitas, Barry Sell, and Louise Burkhart.

\section{Colonial Nahua Musical Practice}

Soon after Cortés landed in the Americas, he and other Spaniards started celebrating mass, which was in part chanted by the priest and accompanied by singing and the playing of musical instruments. According to Stevenson, the native peoples of the Americas were quite taken with European music and soon began to imitate the Spaniards. ${ }^{6}$ As early as 1527 fray Pedro de Gante began to train Nahua singers in European music. And music was deemed important enough that fray Juan Caro taught classes in the Colegio de San Josef designed to improve mass. ${ }^{7}$ In 1532 fray Martín de Valencia, head of the Franciscan order in New Spain, wrote a letter to Charles V in which he explained that the Franciscans trained Nahua cantores, singers, in two types of vocal music, plainsong, similar to Gregorian chant, and polyphonic, or part-music, and provided instruction in how to sing the canonical hours and help with mass. ${ }^{8}$ The same year fray Pedro wrote to Charles V, claiming that some of the cantores at San Josef possessed skills equivalent to Charles's personal chapel choir. ${ }^{9}$

The apparent speed with which Nahuas adopted Christian music was aided by their precontact musical traditions. Their instruments tended to be percussion or wind. Examples are the teponaztli (Figure 1), a slit-drum made from a meterlong section of tree trunk with two holes on opposing sides; the omitzicabuaztli,

5. Lourdes Turrent, La conquista musical de México (México: Fondo de Cultura Económica, 1993); and Eloy Cruz, "De cómo una letra hace la diferencia: Las obras en Náhuatl atribuidas a don Hernando Franco," Estudios de Cultura Náhuatl 32 (2001), pp. 257-295.

6. Stevenson, Music in Mexico, p. 51.

7. Gerónimo de Mendieta, Historia exlesiástica indiana, 2 vols. (México: Consejo Nacional para la Cultura y las Artes, 1997), vol. 2, pp. 75-76.

8. Archivo Histórico Nacional, Madrid (AHN), Diversos Colecciones 22, N 13.

9. Cartas de Indias: Facsimile of 1877 Madid Manuel G. Hernández Edition, 2 vols., ed. Edmundo Aviña Levy (Guadalajara, México, 1970), vol. 1, p. 56. 
Figure 1

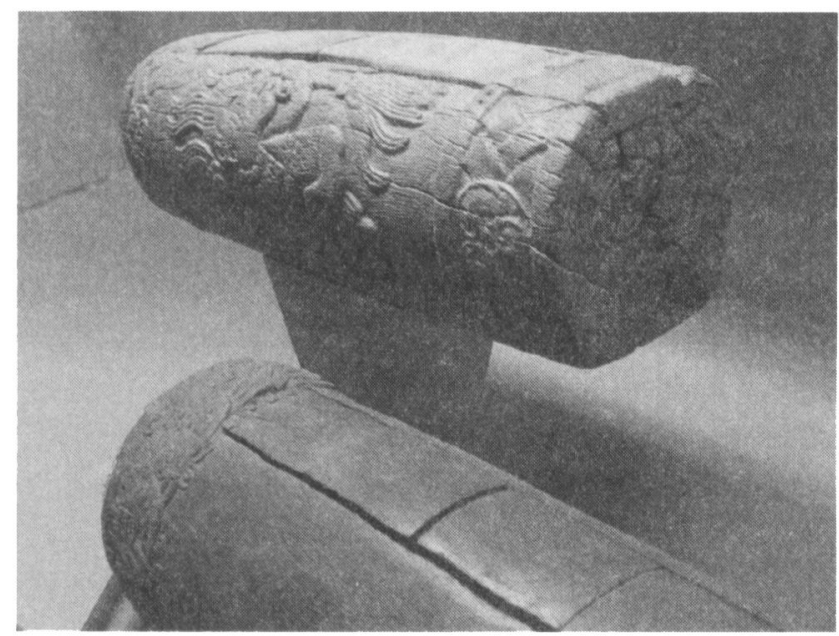

Source: Wikimedia Commons [http://commons.wikimedia.org/wiki/File:Two_Teponaztli.jpg]

a rasp of wood or bone constructed from a larger serrated piece that was scraped by a smaller stick; the ayacachtli, a rattle-like instrument created with a dried gourd; the tlapitzalli, a trumpet or flute made from shell or bone; the quiquiztli, a conch shell trumpet; and the buebuetl (Figure 2), a three-foot-high cylindrical drum. Based on indigenous codices and carvings, it appears that indigenous peoples played music in accompaniment at religious and political ceremonies. Musicians during this period were well trained and enjoyed high social rank because of their skills. ${ }^{10}$

According to fray Toribio de Benavente (Motolinía), precontact indigenous nobility frequently supported household singers, who also composed new songs and dances. Song and dance had a central role in many of the larger public celebrations that occurred every 20 days. Concerts were a communal rather than a solo affair and were often accompanied by dancing, singing, and probably a certain degree of pageantry. Musicians needed to know the appropriate routine for each celebration within the 260-day religious cycle and probably spent much of their time preparing for their performances, as mistakes were deemed offensive to the gods. ${ }^{11}$ Depending on the celebration, music could start in the early morning and continue until midnight. Both Motolinía and fray Bernardino de Sahagún state that musical mistakes were not tolerated at religious ceremonies, the offending party's punishment apparently being execution. Sahagún also mentioned that

10. Stevenson, Music in Mexico, pp. 8-13, 18-19; and Stanley Sadie, ed., The New Grove Dictionary of Musical Instruments, 3 vols. (London: Macmillan Press Limited, 1984), vol. 1, p. 91; vol. 2, pp. 258, 816; vol. 3, pp. 567, 601.

11. Stevenson, Music in Mexico, pp. 17-19. 
Figure 2

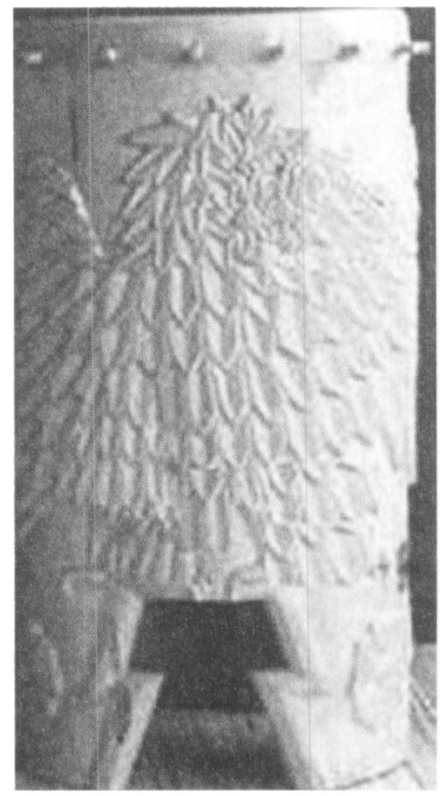

Source: Wikimedia Commons [http://commons.wikimedia.org/wiki/File:Two_Teponaztli.jpg]

boys trained for the precontact indigenous priesthood received musical training as part of their education. ${ }^{12}$

The Nahuas' association of music with religious ceremonies and their enjoyment of music in general, in addition to its position as a communal endeavor, probably contributed to the speed with which they learned and adopted European music. ${ }^{13}$ Music, as much as writing, came to play a pervasive role in the Nahua community of Mexico-Tenochtitlan, and though taught at San Josef, it quickly spread beyond the chapel's confines and into the community as part of confraternity processions, feast day celebrations, theatrical performances, marriages, and burials, among other occasions. During the sixteenth and seventeenth centuries, Nahuas requested that music be played at their funerals and sold instruments in their wills.

Indigenous singers met in their chapels daily to practice. In each chapel there were usually 15 to 16 singers. They performed for mass and the divine office. Chapels were filled with polyphonic singing, as well as the sound of flutes and chirimias, an instrument similar to a clarinet. In many areas their performances included dul-

12. Ibid., pp. 21, 25; and Bernardino de Sahagún, Florentine Codex: General History of the Things of New Spain, 2nd ed. rev., 13 vols., ed. and trans. Charles E. Dibble and Arthur J. O. Anderson (Salt Lake City: School of American Research and University of Utah Press, 1970-1982), vol. 3, p. 67.

13. Stevenson, Music in Mexico, p. 32. 
cimers, oboes, viols, organs, including some of indigenous origin. ${ }^{14}$ During the first half of the sixteenth century, Nahua musical training included both how to play and how to build a specific instrument. Among the instruments they learned to construct were flutes; chirimías; orlos, or regals; vibuelas de arco, guitar-like instruments played with a bow; cornetts; bajones, a bass viola or bassoon; the rabel, a three-stringed instrument played with a bow; guitars; sitars; discantes; small guitars; vihuelas (differing from the vihuela de arco in that a bow is not used), harps, and monochords. ${ }^{15}$

By the mid-sixteenth century friars were scoring Christian psalms, written in Nahuatl, to indigenous music. The best-known example of this is fray Bernardino de Sahagún's Psalmodia Christiana (1583). ${ }^{16}$ Sahagún wrote (or more likely had Nahua students write) the canticles so as to encourage the Nahuas to abandon the old songs they sang to their precontact deities. He wanted his songs, using familiar tunes but different words, to encourage the Nahuas to exalt the Christian God and the saints. He believed that the Psalmodia would help in this endeavor and aid priests working to convert the indigenous peoples of New Spain. Before printing the Psalmodia, Sahagún circulated the manuscript among the indigenous peoples, presumably to be sure they understood and used it. Moreover, he received the support of three viceroys: don Luis de Velasco (the elder) (r. 1550-1564), don Martín Enríquez (r. 1568-1580), and don Lorenzo Suárez de Mendoza, count of Coruña (r. $1580-1583){ }^{17}$

While Sahagún worked on the Psalmodia, another anonymous work on Nahua music was compiled. ${ }^{18}$ The Cantares mexicanos was created from songs taken in oral testimony from Nahua informants during the second half of the sixteenth century. The work originated in Mexico City, although some of it came out of Azcapotzalco. ${ }^{19}$ Many of the songs recorded in the Cantares were based on precontact tradition, but much of their content had clearly been altered to be acceptable to the colonial authorities. For example, a verse from the "Old Man Song" reads:

14. Códice Franciscano: siglo XVI informe de la provincial del santo evangelio al visitador lic. Juan de Ovando. Informe de la provincial de Guadalajara al mismo. Cartas del religiosos, 1533-1569 (México: Salvador Chávez Hayhoe, 1941), pp. 57-58.

15. Mendieta, Historia, vol. 2, p. 76; and Toribio de Motolinia, Historia de los indios de la Nucva España (Barcelona: Linkgua ediciones S.L., 2006), pp. 206-207. In reference to cornett versus cornet, I have chosen the spelling with two $t$ s, both because this spelling is found in music dictionaries and to prevent confusion with the nineteenth-century trumpet-like cornet. For more information on this instrument, see Sadie, New Grope Dictionary, vol. 1, pp. 496-503; and Anthony Baincs, ed., The Oxford Companion to Musical Instruments (Oxford: Oxford University Press, 1992), pp. 80-83.

16. Stevenson, Music in Mexico, p. 33.

17. Bernardino de Sahagún, Psalmodia Christiana (Christian Psalmody), trans. Arthur J. O. Anderson (Salt Lake City: University of Utah Press, 1993), pp. 7-8.

18. These songs have been tentatively attributed to Sahagún and his aides. John Bierhorst, trans., Cantares mexicanos: Songs of the Aztecs (Stanford: Stanford University Press, 1985), pp. 7-9.

19. Bierhorst, Cantares, pp. 7-9. 
San Franco ontlatoa fray pedro ye nechnahuatia nicuicanitl

San Francisco speaks! And [f]ray Pedro commands me as I sing. ${ }^{20}$

The song also employs the terms Obispo, bishop, twice and Dios, God, three times. Despite the modifications, this song, among others, also contained references to many things that had been precious to Nahuas in the precontact period, including turquoise, flowers, and eagles. Moreover, the "Old Man Song" has numerous references to teponaztli, huehuetl, and gourd rattles, indicating that these indigenous instruments were possibly used to accompany the musical piece. ${ }^{21}$ Other songs with at least slight modifications were those used in the palace of Moctezuma. One of the songs of this genre mentions Dios (three times) instead of an indigenous deity. Despite this small European influence, the majority of this song references important precontact items such as jade, quetzal, eagles, and jaguars, thereby emphasizing its indigenous background. ${ }^{22}$

Although friars attempted to convert precontact religious songs to Christian themes, they allowed some traditional tunes to continue in use throughout the colonial period. One such song, deemed religiously safe by the mendicants (at least after alterations to some of the lyrics) was the michcuicatl, fish song. ${ }^{23}$ The Nahua annalist Chimalpahin relates an occasion in 1593 when the michcuicatl was sung in Mexico City at the request of Viceroy don Luis de Velasco. Dancers from different altepetl and tradespeople dressed in their insignia, and voladors, natives who, using ropes, descend headfirst from a pole, also took part in the festivities. ${ }^{24}$

Efforts were also made during the late sixteenth century to write polyphonic pieces with accompanying Nahuatl lyrics. Only two known pieces of polyphonic sheet music in Nahuatl are extant; they are attributed to Hernando Francisco (possibly a Nahua) and most likely date from 1599 . In his thorough examination of the sheet music and historiography surrounding the pieces, Cruz has found that they do not fit with any specific genre of music dating from the period. However, the two pieces, contained in the Códice Valdés, were clearly designed for four- and five-part vocal music. ${ }^{25}$ The lyrics in both pieces focus on the Virgin Mary, lack the precon-

20. Ibid., pp. 179-181. The fray Pedro mentioned here was most likely fray Pedro de Gante, probably in reference to his instruction of the Nahuas in European verse.

21. Ibid., pp. 179-183.

22. Ibid., pp. 182-185.

23. For an example of this song, see Bierhorst, Cantares, pp. 277-287.

24. Domingo de San Antón Muñon Chimalpahin Quauhtlehuanitzin, Annals of His Time, ed. and trans. James Lockhart, Susan Schroeder, and Doris Namala (Stanford: Stanford University Press, 2006), p. 45. The song was also performed in 1566, although on this occasion it was at Tepeyacac. Juan Bautista, ¿Cómo te confundes? ¿Acaso no somos conquistados?: Anales de Juan Bautista, ed. and trans. Luis Reyes García (México: Centro de Investigaciones y Estudios Superiores en Antropología Social: Biblioteca Lorenzo Boturini Insigne y Nacional Basílica de Guadalupe, 2001), p. 151. It is possible that there were multiple michcuicatl and that instead of being a specific song it was actually a genre. Chimalpahin, Annals, p. 45 n. 5.

25. Cruz, "De cómo una letra," pp. 257-259. Cruz also provides a facsimile and translation of the sheet music. 
tact imagery of some of the lyrics found in the Psalmodia and Cantares collections, and may have been intended for use in the cathedral (based on the other liturgical music surrounding it). ${ }^{26}$ Its potential use in the cathedral or its later provenance may explain the absence of precontact imagery.

Private use of indigenous musical performances may have maintained a tie to precontact traditions as well. This is hinted at in the 1699 will of Melchora de Santiago. While she did not carry the honorary title doña, she still held a relatively high rank in Nahua society. Her father was don Juan de Santiago, who possessed cacicazgo land, that is, land held by an indigenous ruler, in San Juan Cochtocan. He passed this land, as well as an image of Nuestra Señora de la Purificación, on to his daughter at the time of his death. Similarly, when she died, de Santiago bequeathed half of the money from the cacicazgo to her adopted daughter and left the other half to provide for the holy image, which was left to the daughter once she came of age. The care of the image included money for a high mass, a priest on the saint's feast day, and four reales for singers. ${ }^{27}$ Though these indigenous singers were well removed from the precontact period, they still performed for a religious image, and at the request of wealthy, high-ranking Nahuas. It is difficult to know with any certainty how the latter practice had existed in Mexico-Tenochtitlan. However, it is known that Nahuas in Mexico City had owned personal images of saints as early as $1570 .{ }^{28}$

As a cultural expression in most societies, music has the ability to move across societal barriers with greater ease than some other traditions. As evidenced by Gante's indigenous choir, Spaniards seem to have appreciated this possibility and used it to engage other indigenous groups as well. In 1584 a group of Spaniards traveling to the Philippines initially planned to bring four Nahuas trained to play wind instruments with them (the specific type of instruments is unspecified). However, before the expedition left the shores of New Spain, they exchanged the four musicians for a single Nahua skilled in playing the chirimía. In 1591, when a large group of Tlaxcalteca (natives from Tlaxcala) left for New Mexico, two Nahuas from MexicoTenochtitlan (most likely a fifer and a drummer) escorted the archbishop don Pedro Moya de Contreras to bid them farewell. It is likely that the party took musical instruments with them. But even if instruments did not accompany that group, cornetts, chirimías, trombones, an organ, and bells arrived in New Mexico in the summer of 1609 with two unnamed Franciscans and 20 soldiers. The company also carried primers for teaching and European paper and nails. ${ }^{29}$ The choice of instruments probably reflects their intended use, to accompany European, and probably

26. Ibid., pp. 273-274.

27. Newberry Library Ayer Collection (NL AC), MS 1481 B (3) 1.

28. Bibliothèque Nationale de Paris (BNP), Fondo Mexicains (FM) 112.

29. Chimalpahin, Annals, pp. 29, 37, 157. 
indigenous, choirs. ${ }^{30}$ Clearly, music continued to have an important role in Franciscan missionary efforts in the Philippines and New Mexico.

Many of the European instruments were different enough from indigenous instruments that Nahuas adopted them as loanwords as they wrote and spoke, such as the cornett, chirimía, and the organ. The chirimía alone appears as a loanword as early as the 1560s. The use of Spanish loanwords suggests the prevalence of specific instruments in indigenous society. Moreover, the espousal of specific instruments demonstrates a desire to adopt them into their culture. In contrast, other instruments (to which Nahuas may have been less exposed), such as the trombone, or facapoch, received a Nahuatl name. ${ }^{31}$

Music held a central position during celebratory occasions as well. In September 1593 Mexico City leaders organized a festival that brought tradespeople from many of the surrounding altepetl, including Xochimilco and Tacuba. Dancing and singing took place during many festivities, to the wonderment of Spanish officials. ${ }^{32}$ However, the services of Nahua musicians went beyond the religious and community needs of Nahuas and extended to Mexico City as a whole. As early as 1531 they took part in celebrations for the arrival of important colonial administrators. While initially relatively small in size, viceregal entry celebrations at their height (1585-1700) witnessed an increase in participation by Native Americans. An example is the 1640 arrival of the new viceroy, don Diego López Pacheco, marquis of Villena. Before entering the city, he stopped at the Chapultepec palace just outside Mexico City, where among other festivities 400 indigenous people danced for him, probably accompanied by music. When the viceroy left Chapultepec and entered Tlatelolco he met Mexico City's most powerful officials; with them were 25 Nahua musicians trained in the trumpet, chirimía, and drum. Five additional days of festivities followed his arrival, during which more indigenous music and dancing were performed. ${ }^{33}$ While the celebrations were secular in nature, Nahua musicians employed the instrumental portion of their religious education to partake in some of the festivities.

European-style music quickly became popular among the indigenous peoples of New Spain, no doubt helped by the reduction in tribute payments received by indigenous musicians. This likely led many unskilled musicians to take part in per-

30. Sadie, New Grove Dictionary, vol. 1, p. 501.

31. Bautista, ¿Cómo te confundes?, pp. 196-197; Chimalpahin, Annals, pp. 156-157; and James Lockhart, The Nahuas after the Conquest: A Social and Cultural History of the Indians of Central Mexico, Sixteenth through Eighteenth Centuries (Stanford: Stanford University Press, 1992), p. 285. These were by no means the only instruments in use during the colonial period, as Spaniards and Nahuas also played fifes, drums, and harps, to name a few.

32. Chimalpahin, Annals, p. 45.

33. Linda Curcio-Nagy, The Great Festipals of Colonial Mexico City: Performing Power and Identity (Albuquerque: University of New Mexico Press, 2004), pp. 15-16, 19, 44. 
formances as well. Motolinía states that many of them had difficulty learning how to use the chirimía. Moreover, in 1555 the colonial Catholic Church took steps to ban the playing of trumpets, flutes, and chirimías inside chapels, except in provincial areas. The vihuela de arco was banned altogether. In 1561 Philip II tried to limit the number of musicians as well, though whether for the purpose of receiving more tribute or to improve the quality of the musicians is difficult to know. ${ }^{34}$

Sixteenth- and seventeenth-century testaments from Mexico City and surrounding areas provide additional information about music. An examination of indigenous wills strengthens the evidence found in the annals of Chimalpahin and Franciscan chronicles regarding the importance of music to Nahua society. During the sixteenth century, instruments appear to have been owned by men, and they sold them in their testaments. Intriguingly, in almost all cases instruments were not bequeathed to an individual but rather sold for the proceeds, suggesting that fathers did not necessarily train their sons to perform. The money from the sales went to pay debts or for masses. In only one case was an instrument bequeathed to another individual. This occurred in Culhuacan when both a teponaztli and a huehuetl were given to the amiztlatoa, ward head, for use in public entertainment. Also of note during this time is that the majority of the instruments sold in testaments were drums, although a flute was also documented during this period. ${ }^{35}$ In addition, though they do not make an appearance in this collection of testaments, guitars were sold in Mexico City markets by the 1540s or 1550s. ${ }^{36}$ The men who owned these instruments during the sixteenth century appear to have had a slightly elevated status; some carried the title "don" or still possessed an indigenous surname. In contrast, some seventeenth-century instrument owners lack any distinct indication of social status within the community. Unfortunately, a scarcity of sources makes it difficult to provide more than a conjecture on this matter.

34. Motolinía, Historia, p. 207; and Robert Ricard, The Spiritual Conquest of Mexico: An Essay on the Apostolate and Evangelizing Methods of the Mendicant Orders in New Spain: 1523-1572, trans. Lesley Byrd Simpson (Berkeley: University of California Press, 1966), pp. 178-179.

35. AGN Tierras, v. 35, e. 1; AGN Tierras, v. 22 pt. 1, e. 5; BNP FM 112; AGN Tierras, v. 42, e. 5; AGN Tierras, v. 48, e. 4; AGN Tierras, v. 49, e. 5; Newberry Library (NL) Ayer Collection (AC), MS 1481 B (1) a; AGN Tierras, v. 54, e. 5; AGN Tierras, v. 1774; c. 10; AGN Tierras, v. 59, e. 3; AGN Tierras, v. 70, e. 4; AGN Bienes Nacionales, v. 965, e. 6; AGN Tierras, v. 1595, e. 4; AGN Tierras, v. 3663, e. 3; AGN Tierras, v. 101, e. 2; BNP, FM 255; AGN Bienes Nacionales, v. 387, e. 1; NL AC, MS 1481 F5; AGN Bienes Nacionales, v. 70, e. 3; AGN Bienes Nacionales, v. 1766 ; e. 7; NL AC, MS 1481 B (3) a; Universidad Nacional Autónoma de México, Biblioteca Nacional (UNAM) Fondo Reservado: Archivo Franciscano (FRAF), caja 96, e. 1413; NL AC, MS 1481 B (3) e; AGN Bienes Nacionales, v. 1096, e. 8; NL AC, MS 1481 B (3) F; AGN Tierras, v. 163, e. 2; AGN Civil, v. 1763, e. 2; AGN Civil, v. 1828, e. 5; AGN Civil, v. 592 , e. 1; NL AC, MS 1481 B (3) 1; AGN Tierras, 20 pt. 1, e. 3; AGN Tierras, v. 38, e. 2; AGN Bienes Nacionales, v. 293, e. 1; AGN Tierras; e. 5; AGN Tierras, v. 95 pt. 2, e. 8; AGN Tierras, v. 157, e. 7; AGN Tierras, v. 3711, c. 2; AGN Tierras, v. 1720, e. 7; AGN Bienes Nacionales, v. 339, e. 6; AGN Tierras, v. 109, e. 4; AGN Bienes Nacionales, v. 489, e. 2; NL AC, MS 1481 B (3) b; AGN Tierras, v. 2776 pt. 1, e. 18; NL AC, MS 1481 B (3) d; Instituto Nacional de Antropología e Historia, Archivo Histórico (INAH) Colegio de San Gregorio (CSG), v. 119; AGN Civil, v. 592; e. 1; AGN Tierras, v. 155, e. 9; and S. L. Cline and Miguel León-Portilla, Testaments of Culhuacan (Los Angeles: UCLA Latin American Center Publications and the University of California Press, 1984), documents 14, 50, 92, and 95. It is likely that the drums being sold in these testaments were heirlooms from precontact times.

36. Lockhart, Nabuas, p. 188. 
The seventeenth century witnessed a number of changes. First, by 1677 women were purchasing and selling instruments. In one testament Micaela Angelina, a woman of some wealth, had three harps she wanted sold following her death. Her husband inherited considerable property and money from her but not her harps. Her decision to sell rather than bequeath the instruments demonstrates that they were hers, not his. It is not possible to tell how she came by them, though if other testaments are an example, it is likely that she purchased rather than inherited them. Second, by mid-century Nahuas, both women and men, had started purchasing and selling European-style instruments, such as the harps and guitars mentioned above ${ }^{37}$ Moreover, some musicians, such as Gaspar de los Reyes, were specifically associated with their instruments. In a 1691 census-like document, de los Reyes was listed as a guitarrero, guitar player. This designation suggests at least a degree of proficiency with the European instrument. ${ }^{38}$ The association of Nahuas with harps and guitars appears to have been a common enough occurrence that an anonymous seventeenth-century painting, of an indigenous wedding, included both a native harpist and a guitarist. ${ }^{39}$ Finally, as suggested by Micaela Angelina's ownership of not one but three harps, women may have started playing musical instruments by this time.

Vocal music also played an important role during the colonial period. Indigenous cantores, prominent during both the sixteenth and seventeenth centuries, appear to have achieved a degree of independence from their chaplains by the mid-seventeenth century, something they may not have enjoyed during their period of initial instruction in the sixteenth century. As discussed earlier, the length of time it took to train cantores provided them with a certain amount of job security. They paid half the amount of tribute of other indigenous men and possessed a guaranteed income for their weekly responsibilities at Sunday Mass and on other occasions. Yet while the cantores of the chapel of San Josef were clearly a part of the institution of the Church, they acted independently of the Franciscans to fulfill many of their community responsibilities, as seen in the case mentioned below.

In 1640 a high-ranking indigenous woman named Clara López requested that the cantores of San Josef perform at her burial. Her executor, the indigenous governor of Mexico-Tenochtitlan, don Juan de Aguilar, arranged her burial with the Nahua choirmaster for July 23,1640 . The choir performed part-singing for a fee of five pesos. The brief document concerning this transaction is revealing in what it says and what it does not.

37. NL AC, MS $1481 \mathrm{~B}(3) \mathrm{e}$; and NL AC, MS $1481 \mathrm{~B}(3)$ a.

38. AGN Historía, vol. 413, e. 1.

39. Ilona Katzew, Casta Painting: Images of Race in Eighteenth-Century Mexico (New Haven: Yale University Press, 2004), p. 176. Thank you to Sarah Cline for sharing this image with me. 
Yn axcan martes a 23 d. Julio d. 1640 años otictocaque yn tehuantin cantores nican capilla San Juseph yn omomiquili yn itoca ocatca clara lopes chane tianquiztenco auh yn yehuatzin señor Juan de aguilar albasea omochiuh yehuatzin otechmotlaxtlahuili macuili pesos otechmomaquili ynicc omotocac moch ica ynicc omochiuh yn imisa cuerpo preçente mochi canto de organo huel mahuiztic ynicc otictocaque auh yni macuili pesos nehuatl nomaticca oniccuic: nicçeli yn nehuatl maestro nican capilla sanc juseph mochintin yn ixpa yn ermanos cantores auh ynic nelriliztli melahuac nican nictlalia yn notoca yhuan yn nofirma ffecho e mexico

Francisco de San Juan Maestro de la capilla.

5 pesos.

Today, Tuesday the $23 \mathrm{rd}$ of July of the year of 1640 , we the singers [or cantors] here at the chapel of San Josef buried the deceased person who was named Clara López, citizen of Tianquiztenco. Señor Juan de Aguilar, who was made executor, paid us 5 pesos. He gave it to us for burying her, including the performance of her mass in the presence of the body, complete with part-singing. How we buried her was very splendid. And I the [choir]master here in the chapel of Josef took these 5 pesos in my hand; I received them before the brothers cantors. And [to show] that it is authentic and true I place here my name and signature. Done in Mexico [City].

Francisco de San Juan, choirmaster.

5 pesos. ${ }^{40}$

The exchange was not recorded or even witnessed by a friar or notary; rather, the choirmaster wrote and signed the document in front of Aguilar, and the cantores of San Josef acted as witnesses. This suggests that the choirmaster was in charge of the choir's engagements. It may also be that members of indigenous choirs were literate and could read music, as is suggested by an image from the Florentine Codex (Figure 3). The figure clearly displays two indigenous singers one of whom is holding what is potentially sheet music. The speech scrolls emanating from the figures' mouths suggest that they are in the act of singing. ${ }^{41}$ Yet a third source, the sheet music found in the Códice Valdés, lends credence to Nahua singers' ability to read. ${ }^{42}$ Indeed, as is hinted at by the name attributed to the sheet music, Hernando Francisco (two Spanish first names, suggesting a person of indigenous heritage) and fray Juan de Torquemada's admission that Nahuas copied plainsong and polyphonic music and eventually composed at least polyphonic music, some Nahua musicians were exceedingly literate. ${ }^{43}$ Others, however, probably memorized the lyrics and music for performance.

40. AGN, Bienes Nacionales, vol. 387, e. 1, fs. 15. Special thanks to James Lockhart and Susan Schroeder for providing input and assistance on both this document and others.

41. Sahagún, Florentine Codex, vol. 11 image 43.

42. For more information on the Códice Valdés, see Cruz, "De cómo una letra."

43. Stevenson, Music in Aztec, pp. 171-172. 
Figure 3

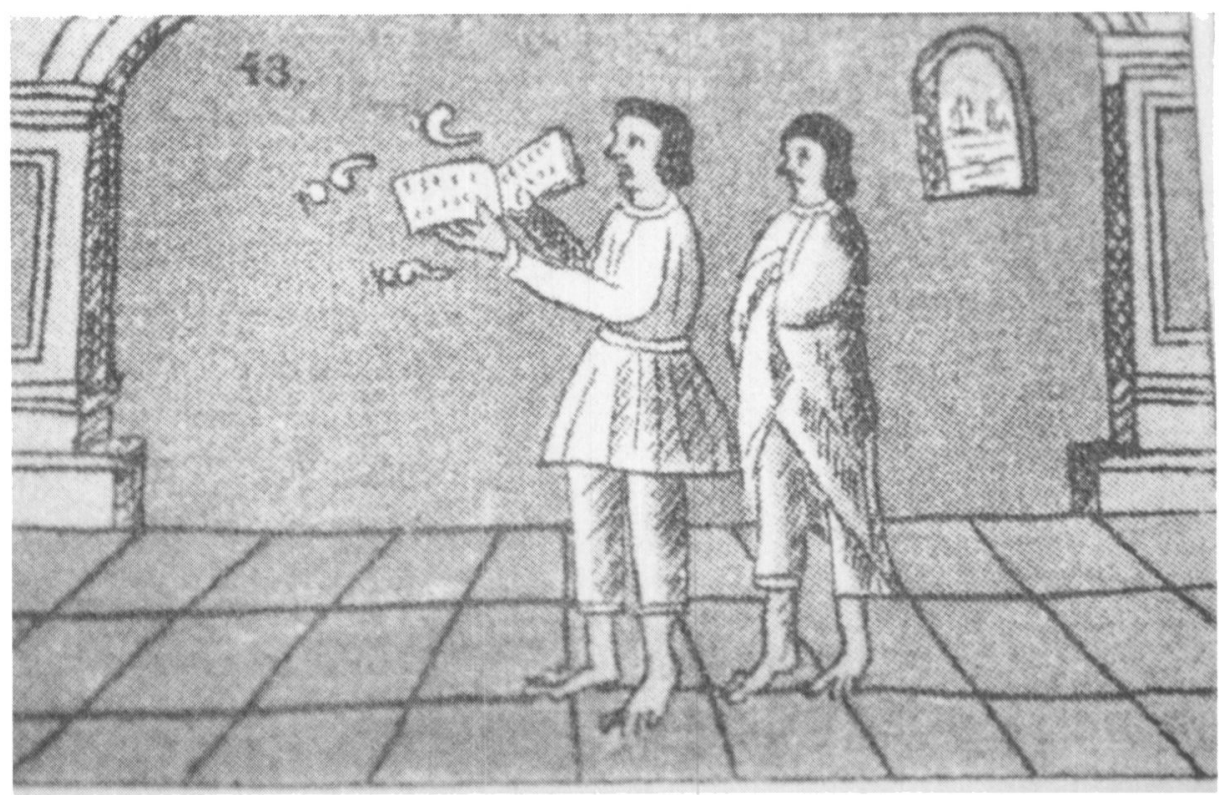

Source: Cantores, Sahagún, Florentine Codex, v. 11 image 43.

To return to the burial agreement, in the document the cantores did not refer to themselves by the indigenous term for singer, cuicani, but instead chose to use the Spanish term, cantor. Moreover, they used the Spanish phrase canto de órgano, polyphonic singing, to refer to the specific type of performance they used at the burial. And the choirmaster referred to his fellow musicians in Spanish terms, using "ermanos cantores," brother singers, rather than an indigenous phrase. The use of the term cantores in the mid-seventeenth century is not surprising. However, the word [h]ermanos is, as kinship terms did not traditionally undergo a change from Nahuatl to Spanish until later. This suggests that the Spanish word for "brother" had been adopted, in this case at least, to refer to a fraternal rather than blood relationship, that is, between colleagues. ${ }^{44}$ Clearly, by 1640 the Franciscans believed the cantores of San Josef were skilled and able to function independently of ecclesiastical oversight. In addition, the Nahuas knew the songs and could differentiate between musical genres. They had taken the musical education they received from the Franciscans and incorporated it into their culture and society.

Members of the Nahua community played a multitude of European and indigenous instruments and possessed training in vocal music. Some Nahuas owned their instruments, while more expensive instruments (e.g., trombones and organs) were 
probably maintained by the mendicant orders and used primarily for religious ceremonies. While Nahuas performed for official Church celebrations, they also used their instruments, and traditional songs, for community festivities and larger city celebrations. Finally, although music appears to have been a male-dominated field, by the last half of the seventeenth century some Nahua women owned their own instruments and may have learned to play them as well.

Music continued to be performed alongside religious and theatrical occasions (e.g., arrival of a new viceroy) in both Spanish and Nahua communities during the sixteenth and seventeenth centuries. The incorporation of music into Nahuatl dramas would not have been a difficult addition to make and was probably facilitated by a similar inclusion in Spanish theater. Moreover, it is possible that the friars approved of the endeavor, as they themselves enjoyed both artistic forms and were frequently responsible for supervising the publication of Nahuatl texts. Though it is probable that they did not pay close attention to all scripts, instrumental music does not appear to have been a limiting factor in whether or not they were deemed appropriate for an indigenous audience.

\section{Staging Catholicism: \\ From Traching Tool to Ancestral Tradition}

In the Americas religious dramas were written in only two known native languages, Nahuatl and Quechua. ${ }^{45}$ As a tool of evangelization, religious dramas started to appear after the introduction of alphabetic script and music. The first known play performed in New Spain occurred in 1533 in Mexico Tlatelolco. In general, Nahuas wrote their scripts in Nahuatl and conducted performances in Nahuatl, and they eventually used musical cues differently than their European counterparts. This mode of proselytization was especially appealing to the Nahuas, due to its similarity to their traditional religious ceremonies, which had emphasized public rituals more than preaching for private worship. Nahua playwrights, working independent of priestly oversight or acting in tandem with friars, penned or translated the scripts. Many of the dramas originated from preexisting Spanish plays. Others, however, were created for the local scene. ${ }^{46}$

Nahuas were accustomed to theatrical performances, and many of their precontact religious ceremonies were accompanied by music and had a performative nature. In some rites a person dressed as a deity interacted with priests in an established

45. For information on dramas in Quechua, see Margot Beyersdorff, Historia y drama ritual en los andes bolivianos $(x v i-x x)$, 2nd ed. (La Paz, Bolivia: Universidad Mayor de San Andrés, 1993). Special thanks to Louise Burkhart for directing me to this source.

46. Sell and Burkhart, Nabuatl Theater Volume 1, p. ix. 
pattern, often depicting a specific deed attributed to the god.$^{47}$ Moreover, much of what the Catholic priests did at Sunday mass, though shrouded in the mystery of a foreign culture and language, possessed a theatrical quality. This is seen especially in the specific dress worn by priests and deacons, the props employed (e.g., crucifixes), and the orchestrated movements performed by the priests as they approached the altar. However, the dramatic enactments of the colonial period situated many Nahuas in the position to "perform" the new religion, or at the very least act out portions of it. But it also placed the actors (and eventually actresses) in a position to instruct their fellow community members in the tenets of their understanding of Christianity.

As with European music, the Nahuas of Mexico-Tenochtitlan incorporated theater into their culture and society, and it became a public form of religious expression. Nahuas helped write many of the scripts, copied others, and passed them from barrio to barrio and altepetl to altepetl. By the end of the seventeenth century and the beginning of the eighteenth, the Nahuas had come to view religious drama as part of their cultural heritage. Colonial authorities, on the other hand, viewed them as heretical and sought to repress both their performances and the scripts. As Burkhart argues, "The performance of plays was . . . one arena in which indigenous communities strove to control their own affairs, their own self-definition and self-expression, enacted in communal ritual." ${ }^{\text {48 }}$

Play enactments occurred in or next to indigenous chapels throughout New Spain. These venues, in combination with the friary courtyards outside them, provided a stage for their performance and space for spectators, such as Nahuas, priests, Spanish officials, or foreign visitors. As the largest indigenous chapel in MexicoTenochtitlan, San Josef was especially well situated as a center for theatrical performances. While the incorporation of theater into Nahua culture appears to have happened at a pace similar to that of alphabetic literacy, European music, confraternities, and other institutions, religious drama eventually came into open conflict in the indigenous parishes of Mexico City, with Spanish ecclesiastics on one side and Nahuas on the other. ${ }^{49}$

47. Louise M. Burkhart, Holy Wednesday: A Nabua Drama from Early Colonial Mexico (Philadelphia: University of Pennsylvania Press, 1996).

48. AGN Bienes Nacionales, vol. 1076 exp. 9; AGN Bienes Nacionales vol. 990 exp. 10; and Louise M. Burkhart, "Pageantry, Passion, and Punishment: Eighteenth-Century Nahuatl Community Theater," in Nahuatl Theater Volume 4: Nabua Christianity in Performance, ed. and trans. Barry D. Sell and Louise M. Burkhart (Norman: University of Oklahoma Press, 2009).

49. AGN Bienes Nacionales, vol. 990 exp. 10; Sell and Burkhart, Nahuatl Theater Volume 4. 


\section{Background and Development of Theater in Mexico CitT}

Of roughly 20 known Nahuatl plays from the sixteenth century, the majority were the product of the Franciscans' evangelization efforts. Franciscans and Nahuas produced most of the plays at one of their larger religious compounds. Horcasitas found that from 1531 to 1600 there were five documented performances in Mexico City. Burkhart has uncovered an additional play that may have made its debut at the chapel of San Josef in the 1590s. Moreover, by the end of the seventeenth century Nahuas performed a "Passion" play annually on Palm Sunday. The play, El Juicio Final, by fray Andrés de Olmos, was performed in 1533 and is the earliest known example of an evangelization drama in Mexico City. ${ }^{50}$ Approximately 800 Nahuas took part in the play, and it was watched by Archbishop fray Juan de Zumárraga. Fray Bartolomé de las Casas, amazed by the report of the play, stated that the 16 Nahua actors with speaking roles were responsible for their own lines, that no one cut another person off, and that their performance was the talk of Europe. ${ }^{51}$

Plays continued to be performed at the request of both Nahuas and Franciscans. The end of the sixteenth and beginning of the seventeenth century saw the introduction of the Holy Wednesday drama. ${ }^{52}$ Chimalpahin mentions that on February 20,1600 , the first day of Lent, fray Juan de Torquemada directed a play "as a model for the lives of us commoners." ${ }^{53}$ Numerous plays were written, copied, and translated in the seventeenth century, some in Mexico City and others in surrounding areas. Some have no known Spanish predecessors; others, such as those translated by don Bartolomé de Alva, are clearly translations into Nahuatl and at times modifications of Spanish Golden Age drama. Alva himself, a mestizo priest descended from Tetzcocan nobility, provided Nahuatl translations of some of the works of Lope de Vega Carpio and Pedro Calderón de la Barca. Although Alva wrote the dramas to help the Jesuit Father Horacio Carochi with his linguistic research into Nahuatl, he wrote them for performance as well. ${ }^{54}$

50. Domingo de San Antón Muñon Chimalpahin Quauhtlehuanitzin, Las ocho relaciones y el memoreal de Colbuacan, 2 vols., trans. Rafael Tena (México: Consejo Nacional para la Cultura y las Artes, 1998), vol. 2, p. 187; Fernando Horcasitas, El teatro Nahuatl: Épocas novohispana y moderna (México: Universidad Nacional Autónoma de México, 1974), pp. 76-79; Burkhart, Holy Wednesday, pp. 81-86; and Agustín de Vetancurt, Teatro mexicano (México: Editorial Porrúa, 1982), pt. 4, p. 42.

51. Ricard, Spiritual, p. 195; and Bartolomé de las Casas, Apologética historia sumaria: Cuanto a las cualidades dispusicion, descripcion, cielo y suelo destas tierras, y condiciones naturals, policies, republicas, manera de vivir e costumbres de las gentes desta indias occidentals y meridionales cuyo imperio soberano pertenece a los reyes de castilla, 2 vols. (México: Universidad Nacional Autónoma de México Instituto de Investigaciones Históricas, 1967), vol. 1, p. 334.

52. It is unknown if this play was performed, although the script was likely written during the 1590s. Burkhart, Holy Wednesday, pp. 82-83.

53. Chimalpahin, Annals, p. 67.

54. See Sell and Burkhart, Nahuatl Theater Volume l; and Barry D. Sell, Louise M. Burkhart, and Elizabeth R. Wright, Nabuatl Theater Volume 3: Spanish Golden Age Drama in Mexican Translation (Norman: University of Oklahoma Press, 2008), pp. xvii-xviii. 
Theatrical performances eventually also incorporated music. Spanish Golden Age drama used both instrumental and vocal music, as evidenced by stage directions in Calderón's The Great Theater of the World. Alva included many, though by no means all, of the musical stage directions in his translation of the work and often altered some of them. In one instance Calderón's version states simply, "Music plays as two spheres open in half at the same time." Alva's version of this paints a similar scene, but the music differs. His stage directions call for "a song, and music made on an organ." ${ }^{25}$ However, a small musical cue similar to Calderón's suggests a possible innovation in Nahuatl theater. The change occurs when the actor playing the part of "Our Savior" exits the stage. In the Nahuatl version "musical instruments are played"; in the Spanish script, no music, of any type, is mentioned. Moreover, there is no scene change or other action mentioned. This is unlike the Spanish cue above that specified the opening of two spheres. ${ }^{56}$ Due to the difficulty of dating Nahuatl scripts, it is not possible at present to say if this was the first occurrence of this type of stage direction. However, by 1678, as evidenced by the script for the Sacrifice of Isaac, such cues were common for characters entering and leaving the stage. In the 24-page script 12 musical cues were used. ${ }^{57}$ While such directions appear in a majority of the known Nahuatl dramas, it is difficult to tell when the trend started. However, musical instruments are noticeably absent from the Holy Wednesday drama (ca. 1590), suggesting that this innovation originated during the seventeenth century. ${ }^{58}$ Based on the description of the cues themselves, it is impossible to determine exactly how elaborate these cues might have been. However, based on certain Nahuas' musical prowess and ability to compose scores, these cues were not necessarily performed by amateur musicians.

The playing of instruments, including drums and wind instruments, when actors entered or left the stage in Nahuatl theater may have started with Alva, but it was certainly in full force among other Nahua playwrights/translators by the 1670 s. The incorporation of music, beyond what Spaniards used in their plays, should not come as a surprise as the Nahuas certainly enjoyed music. It was the Franciscans who introduced the Nahuas to Spanish theater and European musical instruments, but, by the end of the seventeenth century, the Nahuas made them part of their community traditions.

55. Sell, Burkhart, and Wright, Nahuatl Theater Volume 3, pp. 90-91.

56. Ibid., pp. 82-83.

57. Only one cue in the Sacrifice of Isaac called for a named song, specifically, the Misericordia. Sell and Burkhart, Nahuatl Theater Volume 1, p. 159.

58. See script in Sell and Burkhart, Nabuatl Theater Volume 1. 


\section{NELXCUTTILI, AN EXEMPLUM}

Although Spanish in origin, Nahuas did not adopt a Spanish term for their theatrical productions but instead used the term neixcuitilli, initially used to translate Spanish ejemplo or Latin exemplum, or example. ${ }^{59}$ The Nahuas continued to use the term during the colonial period, instead of adopting the Spanish equivalents, auto or comedia, suggesting that they saw the Nahuatl theater genre as distinct and separate from its Spanish counterpart. Spaniards also appear to have understood it as a different type of theater, as they adopted the term into colonial Spanish by the second half of the seventeenth century. When Archbishop don fray Payo Enríquez de Rivera Manrique complained about the Nahuas' "nescuitiles" in Mexico City, in 1673, he did not provide any clarifying remarks, suggesting that anyone who read the document understood what the term meant. ${ }^{60}$ The word continued to appear in other complaints in favor of and against Nahua theatrical performances and was used by fray Agustín de Vetancurt in reference to the Palm Sunday "Passion" play performances in his seventeenth-century chronicle. ${ }^{61}$

Sometime before 1673 and Archbishop Enríquez de Rivera Manrique's complaint, Nahuatl theater had diverged sufficiently from its European counterpart to be considered a genre of its own. Many of the scripts were translated and adapted to fit Nahua culture and society. This was especially the case in don Bartolomé de Alva's translation of Spanish Golden Age dramas. ${ }^{62}$ The alteration of these plays went beyond changing scripted parts and the addition of stage directions, as discussed above. The change in the cues suggests that the Nahuas were not only rewriting the performances but also serving as the directors, or at least influencing the directors, of the performances.

The divergence between Spanish and Nahuatl religious drama caused conflict during the last quarter of the seventeenth century, as briefly mentioned above. The initial concern was with the Mexico Tlatelolco Nahuas' performance of the Easter "Passion" play. However, the complaints eventually included the "Epiphany" neixcuitilli and targeted the additional Mexico City indigenous parishes of San Josef, San Pablo, San Sebastián, Santa María, Santa Cruz, and Mixtecos. ${ }^{63}$ The disagreement was over the Nahuas' portrayal of religious characters, the participation of actresses, and the amount of alcohol imbibed by some thespians. Fray Miguel Camacho Villavicencio said he had to remove the actors playing the apostles from the 1697 production due to drunkenness. He advocated the cessation of such per-

59. Burkhart, Holy Wednesday, p. 46.

60. AGN Bienes Nacionales, vol. 1076, exp. 9.

61. AGN Bienes Nacionales, vol. 990, exp. 10; and Vetancurt, Teatro, pt. 4, p. 42.

62. Louise M. Burkhart, "Nahuatl Baroque: How Alva Mexicanized the Spanish Dramas," in Sell, Burkhart, and Wright, Nabuatl Theater Volume 3, p. 35.

63. AGN Bienes Nacionales, vol. 990, exp. 10. 
formances, stating that visual spectacles of Christian narratives were not needed, since Nahua parishioners could learn as well from simply listening to the stories. However, both he and the 15 high-ranking Nahuas petitioning for permission to continue performing the "Passion" narrative state that the play traced to the early colonial period. The Nahuas described the play as a very old tradition. ${ }^{64}$

In 1704 Archbishop don Juan de Ortega Cañon Montañez y Patiño affirmed his predecessor's decree against the performance of the "Passion" and "Epiphany" neixcuitilli. He sent his edict to the seven indigenous parishes in Mexico City and had the chaplains sign off on the document, stating that they both heard and obeyed the declaration. The authorities objecting to the performances do not appear to have been anti-neixcuitilli; they simply were opposed to Nahua women acting onstage and Nahuas playing the part of Jesus, the apostles, St. Joseph, one of the Marys, or other named saints and angels, especially in the Epiphany and Passion plays. The argument over both neixcuitilli lasted for at least 30 years. Although an agreement was eventually reached between the archbishop and mendicant chaplains, it did not include their indigenous parishioners. Despite Archbishop Ortega Cañon Montañez y Patiño's decree banning the performances, the indigenous peoples of New Spain continued to perform "Passion" neixcuitilli, as evidenced by an eighteenth-century copy of the a Passion play script in Tepaltzingo and the continued performance, to this day, of the Iztapalapa Passion play in Mexico City. ${ }^{65}$

Neixcuitilli continued to be written and performed, and Vetancurt, chaplain of San Josef, supported the composition of another neixcuitilli. Although the play had angels and demons in its cast, none of them was named, nor were there any female roles. Despite attempts to alter their performances, neixcuitilli continued to come under censure from the Inquisition in the eighteenth century. This persecution, however, did not prevent the Nahuas from passing the scripts from one generation and the next or from continuing to stage them. Even "Passion" plays, the target of heated debate, continue to make an appearance in many indigenous villages today. ${ }^{66}$

Nahuatl theater and music started as pedagogical tools used by the Franciscans in the hope of converting the Nahuas of New Spain to Christianity. Theater, unlike music, eventually came under censure by ecclesiastical authorities because of the Nahuas' portrayal of key religious figures and their perceived interpretation of the stories. The argument over the neixcuitilli demonstrates the Nahuas' adoption of this teaching aid and its incorporation into their society. Their struggle to continue

64. Ibid.

65. Ibid. The Iztapalapa passion play is performed every year on Good Friday and is quite possibly the largest performance of the Passion in Mexico. Other Passion plays are enacted in small towns throughout the Mexican countryside as well. For information on the Iztapalapa Passion play, see Richard C. Trexler, Reliving Golgotha: The Passion Play of Iztapalapa (Cambridge, MA: Harvard University Press, 2003).

66. Burkhart, "Pageantry"; and Sell and Burkhart, Nabuatl Theater Volume 4. 
performing theater pieces and their success in doing so, against the desires of multiple archbishops and some Franciscans, reveals a degree of cultural and social autonomy in the capital of New Spain 175 years after the defeat of Mexico-Tenochtitlan.

\section{Conclusion}

By the end of the Hapsburg period, the Nahuas of Mexico City had not only incorporated European-style music and theater into their culture, but they had also combined both artistic styles, altered them, and added them to their perceived ancestral traditions. In some business transactions the Nahua cantores appear to have acted independently of clerical oversight. In addition, both Nahua men and Nahua women started to purchase and possibly play European instruments.

It is unknown how much musical composition happened away from the watchful eyes of religious teachers. However, it is probable that indigenous musical instruction did not remain within the confines of religious compounds. By the 1530s schools for musical instruction, started by Spaniards outside the religious orders, had opened in Mexico City. ${ }^{67}$ It is unknown how many of their students were of indigenous descent. That said, the creation of these schools, the innovativeness of Nahua society, and the existence of one potential female Nahua harpist suggest that Nahuas may have been instructing each other in European musical instruments by the end of the seventeenth century.

While the musical engagements of the Nahuas of Mexico-Tenochtitlan were provided with some independence, the theatrical dramas, which they had been performing since the 1530s, came under censure by the 1670s. The argument over the neixcuitilli demonstrates the Nahuas' adoption of a tool of evangelization and its incorporation into their society. Their ability to persist in its performance during the colonial period attests an independence of their culture and society, even in the capital of New Spain, almost two centuries after Cortés's defeat of Mexico-Tenochtitlan.

Franciscan friars introduced European music and theater to the Nahuas during the first half of the sixteenth century. By the mid-seventeenth century both artistic forms had taken on a life of their own within the Nahua community of MexicoTenochtitlan. Women, excluded during the sixteenth century, were included as participants in both traditions by the end of the seventeenth. And while the Nahuas came into conflict with Church authorities, they persevered in both traditions well into the eighteenth century.

Central Michigan University

JONATHAN TRUITT Mount Pleasant, Michigan

67. Turrent, La conquista, p. 153. 